\title{
HUBUNGAN ANTARA TINGKAT RELIGIUSITAS DENGAN \\ PERILAKU SEKS BEBAS PADA REMAJA MESJID DI DESA CIKUNGKURAK BANDUNG
}

\author{
Bobby G. Hidayatuddin, Ulfiah \& Ening Ningsih \\ Fakultas Psikologi UIN Sunan Gunung Djati Bandung, Jl. A.H Nasution No. 105 Bandung \\ email: bobby.g.hidayat@facebook.com
}

\begin{abstract}
Abstrak
Penelitian ini berawal dari fenomena yang terjadi pada remaja mesjid, dimana mereka suka melakukan kegiatan keagamaan tetapi mereka juga sering melakukan seks bebas seperti berganti-ganti pasangan dalam melakukan hubungan seks bebas, menyewa PSK baik itu dari tempat lokalisasi atau dari pinggir jalan. Pada saat di tanya mereka tahu bahwa perbuatan itu dosa tetapi hasrat dalam dirinya tidak bisa terkontrol itu yang mereka katakan. Dengan demikian dapat dilihat subjek dalam masalah ini memiliki tingkat religiusitas dan perilaku seks bebas yang tinggi. Penelitian ini menggunakan pendekatan kuantitatif dengan metode korelasional. Populasi dalam penelitian ini adalah semua remaja mesjid di desa Cikungkurak Bandung yang berjumlah 102 orang dan tersebar di 4 mesjid. Korelasi antara dua variabel dihitung dengan menggunakan perhitungan statistik korelasi Rank Spearman. Berdasarkan hasil analisis diketahui bahwa koefisien korelasi antara religiusitas dengan perilaku seks bebas adalah sebesar -0,187 dengan taraf signifikansi 0,030 dan $\alpha=0,05$ dengan arah pengujian satu sisi. Karena taraf signifikansi lebih kecil dari pada harga $\alpha$, maka H0 ditolak. Dengan demikian dapat dikatakan bahwa terdapat hubungan negatif antara religiusitas dengan perilaku seks bebas.
\end{abstract}

Kata kunci: Remaja, Keberagamaan, perilaku sex bebas

\section{Abstract}

This research based on phenomena of teenagers who actively join mosque activity but often do free sex such as exchanging partners, paying whore both from the steet and prostitution. They know what they do is a sin but they said that they can not control themselves. It can be said that subjects in this problem have high religious level and high free sex behaviours. This quantitative research used correlational methodology. Population are 120 teenagers around 4 mosques who actively join mosque activity in Cikungkurak Bandung. Correlation between two variables analyzed using statistical correlation Rank Spearman. Result found coefficient correlation between religiousity and free sex behaviour is $-0,187$ with sifnificant level is 0,030 and $\alpha=0,05$. Since significant level is less than $\alpha$, so Ho is rejected. Therefore, it is concluded that there is negative correlation between religiousity and free sex behaviours.

Keywords : teenagers, religiousity, free sex

\section{PENDAHULUAN}

Agama merupakan pegangan dan pedoman bagi perilaku manusia. Maka dari itu peran agama sangat diperlukan karena agama dapat memberikan arah pada manusia dalam bentuk tindakan/perilaku. Agama menurut Glock dan Stark (Ancok dan Fuad, 1994: 76) adalah sistem simbol, sistem keyakinan, sistem nilai dan sistem perilaku yang terlembagakan yang semuanya itu berpusat pada persoalan-persoalan yang dihayati sebagai sesuatu yang paling makna. Keberagamaan itu sendiri adalah ke- 
mampuan seseorang dalam menerapkan dan menginternalisasikan nilai-nilai keagamaan ke dalam kehidupannya dan tercermin dalam sikap dan perilakunya. Religiusitas melibatkan beberapa aspek yaitu aspek kognitif, afektif dan aspek konatif.

Religiusitas diwujudkan dalam berbagai sisi kehidupan manusia. Aktifitas beragama bukan hanya terjadi ketika seseorang melakukan perilaku ritual (beribadah), tetapi juga ketika melakukan aktifitas lain yang didorong oleh kekuatan supranatural. Bukan hanya akan berkaitan dengan aktifitas yang tampak dan dilihat oleh mata, tapi juga aktifitas yang tak tampak dan terjadi dalam hati seseorang.. karena itu, keberagamaan seseorang akan meliputi berbagai macam sisi atau dimensi. Dengan demikian agama adalah sebuah sistem yang berdimensi banyak. Agama menurut Glock dan Stark (dalam Jamaludin Ancok, 1994: 76) adalah sistem simbol, sistem keyakinan, sistem perilaku yang terlembagakan yang semuanya itu berpusat pada persoalan-persoalan yang dihayati sebagai sesuatu yang paling maknawi.

Religiusitas bukan hanya yang berkaitan dengan aktifitas yang tampak dan dilihat oleh mata, tetapi juga aktifitas yang tampak dan terjadi dalam hati seseorang. Karena itu, religiusitas akan meliputi berbagai macam dimensi. Menurut Glock \& Stark ada 5 macam dimensi religiusitas yaitu keyakinan, praktek agama, pengamalan, pengetahuan, dan konsekuensi. Religiusitas melibatkan fungsi jiwa rasa manusia karena didalamnya mencangkup aspekaspek kognitif, yang nampak dalam keimanan dan kepercayaan, afektif terlibat dalam ketuhanan dan rasa keagamaan serta kerinduan pada tuhan, dan konatif nampak dalam perbuatan dan gerakan tingkah laku keagamaan. Aspekaspek tersebut merupakan suatu sistem kesadaran beragama yang telah ada dalam kepribadian seseorang (Ahyadi, 1991: 70). Aspekaspek ini terkandung dalam dimensi-dimensi religiusitas.

Dimensi pengetahuan agama mengacu pada sejauhmana individu memiliki pengetahuan mengenai keagamaan yang melibatkan aspek kognitif. Pengetahuan ini diterima oleh akal/penalaran melalui aspek kognitif. Tanpa ranah kognitif, sulit dibayangkan seorang individu dapat berfikir. Tanpa berfikir mustahil individu dapat meyakini dan memahami faidah-faidah agama yang diterima dan pesan-pesan moral yang terkandung dalam agama ter- sebut. Tingkat pengetahuan yang tinggi dalam berbagai bidang agama akan membuat individu berfikir beberapa kali ketika ia akan melakukan perlaku seks bebas, sehingga tingkat perilaku seks bebasnya pun akan menjadi rendah. Sebaliknya individu yang memiliki tingkat pengetahuan tentang agama yang rendah akan melakukan perilaku seks bebas tanpa berpikir panjang terlebih dahulu sehingga tingkat perilaku seks bebasnya menjadi tinggi.

Dimensi keyakinan mengacu pada kenyatan bahwa agama patut diterima karena kebenarannya. Kebenaran agama tersebut diterima akal. Selain itu, untuk meyakini akan adanya Tuhan, tidak hanya diterima oleh akal tapi juga diterima oleh rasa artinya dirasakan oleh hati. Dengan merasakan adanya keberadaan Allah, Malaikat, kitab-kitab, Nabi dan Rasul, yakin adanya hari akhir dan yang terakhir yakin adanya Qada dan Qadar. Tingkat keyakinan yang tinggi akan adanya berbagai hal ghaib yang diceritakan dalam agama akan membuat remaja selalu merasa diawasi dan dicatat perilakunya. Sehingga ia akan merasa selalu diawasi ketika akan melakukan sesuatu yang bertentangan dengan agama termasuk perilaku seks bebas, akibatnya tingkat perilaku seks bebasnya akan rendah. Sebaliknya remaja yang tidak merasa diawasi akan memunculkan tingkat perilaku seks bebas yang tinggi.

Dimensi praktek agama mengacu pada perilaku ketaatan dan hal-hal yang dilakukan orang untuk menunjukkan komitmen terhadap agama yang dianutnya. Dengan melaksanakan shalat, puasa, infak, shodaqoh dan juga kegiatan-kegiatan agama lainnya. Islam mengajarkan bahwa sholat itu dapat mencegah perbuatan keji dan munkar. Hal tersebut dapat dipahami karena dorongan-dorongan seks yang dimiliki remaja dapat disalurkan melalui aktivitas praktek agama, sehingga tingkat perilaku seksnya menjadi rendah. Sedangkan remaja yang menyalurkan dorongan seksnya dengan berpacaran akan memiliki tingkat perilaku seks yang tinggi.

Dimensi pengalaman bahwa ketika individu mampu berhubungan / berkomunikasi dengan hal supranatural yaitu Tuhan. Individu tersebut mampu merasakan kehadiran Tuhan dan merasakan adanya Tuhan bersamanya artinya individu tersebut merasa dekat dengan Tuhan. Individu juga mampu merasakan ketenangan batin pada saat melaksanakan ibadah sebelum maupun sesudahnya. Individu merasa- 
kan petunjuk dari tuhan dengan mendapatkan kemudahan yang diharapkan. Kemudian individu merasakan perasaan berdosa jika melakukan hal-hal yang tidak benar/tidak sesuai dengan norma-norma agama yang berlaku. Ketika perasaan ini muncul pada remaja, maka ia akan merasa takut tuhan tidak menyertainya lagi ketika ia melanggar aturanNya, sehingga tingkat perilaku seksnya akan menjadi rendah. Sebaliknya remaja yang tidak memiliki perasaan dekat dengan tuhan akan melakukan perilaku apa saja tanpa kendali termasuk berpacaran, sehingga tingkat perilaku seksnya akan menjadi tinggi.

Dimensi konsekuensi berhubungan dengan empat aspek yang sudah dijelaskan sebelumnya. Jika aspek sebelumnya hanya menggariskan bagaimana pemeluknya seharusnya berfikir dan bertindak dalam kehidupan seharihari. Maka aspek ini mengatur konsekuensi agama yang berasal dari komitmen agama itu sendiri apabila aspek sebelumnya dilanggar. Akibatnya ketika remaja akan melakukan perilaku seks bebas ia merasa takut akan mendapat balasan atas perbuatannya, sehingga tingkat perilaku seks bebasnya akan menjadi rendah. Sedangkan remaja yang memiliki tingkat keyakinan yang rendah tidak akan memiliki perasaan takut, sehingga tingkat perilaku seks bebasnya menjadi tinggi. Jadi jika remaja tersebut tidak mempunyai komitmen di dalam dirinya maka akan lebih mudah terjerumus pada perilaku seks bebas. Sebaliknya jika mereka mempunyai komitmen yang kuat untuk tidak melakukan halhal yang dilarang agama maka seks bebas tidak akan terjadi. Jadi, religiusitas adalah kemampuan seseorang dalam menerapkan dan menginternalisasikan nilai-nilai keagamaan ke dalam kehidupannya dan tercermin dalam sikap dan perilakunya.

Pendidikan agama di mesjid, keluarga maupun di sekolah diharapkan dapat menjauhkan dari perbuatan yang menyimpang atau manusia itu sendiri dapat mengontrolnya. Namun sangat disayangkan harapan itu tidak semuanya dapat terealisasi pada sebagian masyarakat Indonesia yang beragama. Seperti halnya yang terjadi pada sebagian remaja di mesjid-mesjid yang berada di desa Cikungkurak Bandung. Beberapa dari mereka terlibat perilaku seks bebas. Padahal berbagai kegiatan yang dilakukan di mesjid di desa tersebut sarat dengan muatan agama. Kadar dan bobotnya menitikberatkan pada agama pastinya. Hal ini dapat dilihat pada pelajaran oleh yang disampaikan oleh ustadz disana, yaitu mempelajari kitab kuning seperti safinah, jurumiah atau pun kitab-kitab lainnya. Ada juga sebagian dari mereka yang pernah masuk pesantren disalah satu pesantren di luar kota Bandung.

Seks Bebas adalah segala tingkah laku yang didorong oleh hasrat seksual, baik dengan lawan jenisnya atau pun dengan sesama jenisnya (Sarlito, 1997: 137). Berdasarkan penelitian yang dilakukan oleh Nuss \& Luckey tahun 1969 (dalam Sarlito, 1997: 160) bentuk perilaku seks bebas adalah berupa aktifitas: a). Memegang, yaitu aktifitas seksual yang menimbulkan rangsangan seksual berupa sentuhan atau belaian dan remasan tangan dengan tangan, tangan dengan tubuh, tangan dengan payudara, tangan dengan pantat dan tangan dengan kelamin. b). Pelukan, Merupakan aktifitas seksual yang menimbulkan rangsangan seksual berupa rangkulan tangan dengan tubuh. c). Ciuman, merupakan aktifitas seksual yang menimbulkan rangsangan berupa sentuhan bibir dengan pipi, bibir dengan bibir dan bibir dengan payudara/dada. d). Petting (bercumbu), merupakan aktifitas seksual yang menimbulkan rangsangan dengan menempelkan alat kelamin tanpa membuka pakaian. e). Senggama, merupakan aktifitas seksual yang menimbulkan rangsangan dengan cara memasukkan alat kelamin laki-laki ke alat kelamin perempuan.

Remaja diharapkan dapat mencapai kehidupan seksual secara dewasa yaitu memiliki kemampuan untuk mengendalikan dorongandorongan seksual serta dapat mengekspresikannya melalui cara-cara yang dapat diterima oleh masyarakat. Disamping itu remaja juga diharapkan memiliki nilai-nilai sebagai pegangan dan menjalani kehidupan seksualnya.

Masa remaja merupakan masa transisi, dimana usianya berkisar antara 13 sampai 22 tahun atau yang biasa disebut dengan usia yang tidak menyenangkan, dimana terjadi juga perubahan pada dirinya baik secara fisik, psikis, maupun secara sosial (Hurlock, 1973). Pada masa transisi tersebut kemungkinan dapat menimbulkan masa krisis, yang ditandai dengan kecenderungan munculnya perilaku menyimpang. Pada kondisi tertentu perilaku menyimpang tersebut akan menjadi perilaku yang mengganggu (Ekowarni, 1993). Melihat kondisi tersebut apabila didukung oleh lingkungan yang kurang kondusif dan sifat kepribadian yang kurang baik akan menjadi pemicu timbulnya ber- 
bagai penyimpangan perilaku dan perbuatanperbuatan negatif yang melanggar aturan dan norma yang ada di masyarakat yang biasa-nya disebut dengan kenakalan remaja.

Kenakalan remaja dalam studi masalah sosial dapat dikategorikan ke dalam pe-ilaku menyimpang. Dalam perspektif perilaku menyimpang masalah sosial terjadi karena terdapat penyimpangan perilaku dari berbagai aturan-aturan sosial ataupun dari nilai dan norma sosial yang berlaku. Perilaku menyimpang dapat dianggap sebagai sumber masalah karena dapat membahayakan tegaknya sistem sosial. Penggunaan konsep perilaku menyimpang secara tersirat mengandung makna bahwa ada jalur baku yang harus ditempuh. Perilaku yang tidak melalui jalur tersebut berarti telah menyimpang. Untuk mengetahui latar belakang perilaku menyimpang perlu membedakan adanya perilaku menyimpang yang tidak disengaja dan yang disengaja, diantaranya karena pelaku kurang memahami aturan-aturan yang ada, perilaku menyimpang yang disengaja, bukan karena pelaku tidak mengetahui aturan. Hal yang relevan untuk memahami bentuk perilaku tersebut, adalah mengapa seseorang melakukan penyimpangan, padahal ia tahu apa yang dilakukan melanggar aturan. Becker (dalam Soerjono Soekanto, 1988) mengatakan bahwa tidak ada alasan untuk mengasumsikan hanya mereka yang menyimpang mempunyai dorongan untuk berbuat demikian. Hal ini disebabkan karena pada dasarnya setiap manusia pasti mengalami dorongan untuk melanggar pada situasi tertentu, tetapi mengapa pada kebanyakan orang tidak menjadi kenyataan yang berwujud penyimpangan, sebab orang pada umumnya dapat menahan diri dari dorongan-dorongan untuk menyimpang.

Kenakalan-kenakalan yang dilakukan oleh remaja di bawah usia 17 tahun sangat beragam mulai dari perbuatan yang amoral dan anti sosial tidak dapat dikategorikan sebagai pelanggaran hukum. Bentuk kenakalan remaja tersebut seperti: kabur dari rumah, membawa senjata tajam, dan kebut-kebutan di jalan, sampai pada perbuatan yang sudah menjurus pada perbuatan kriminal atau perbuatan yang melanggar hukum seperti; pembunuhan, perampokan, pemerkosaan, seks bebas, pemakaian obat-obatan terlarang, dan tindak kekerasan lainnya yang sering diberitakan media-media masa. Hampir setiap hari kasus kenakalan remaja selalu kita temukan di media massa.
Banyak remaja sekarang yang sudah keluar dari ambang batas kewajaran dalam menjalani pergaulan. Salah satunya yang paling menonjol adalah seks bebas atau yang lebih dikenal dengan nama free sex. Mungkin hal-hal seperti itu dilakukan remaja sekarang karena rasa ingin tahu mereka terhadap hal tersebut, ditambah lagi hormon mereka yang sedang mencapai masa-masa puncaknya.

Hubungan seks di luar pernikahan menunjukkan tidak adanya rasa tanggung jawab dan memunculkan rentetan persoalan baru yang menyebabkan gangguan fisik dan psikososial manusia. Bahaya tindakan aborsi, menyebarnya penyakit menular seksual, rusaknya institusi pernikahan, serta ketidakjelasan garis keturunan.

Aktifitas seksual pada dasarnya adalah bagian dari naluri yang pemenuhannya sangat dipengaruhi stimulus dari luar tubuh manusia dan alam berfikirnya. Meminimalkan hal-hal yang merangsang, mengekang ledakan nafsu dan menguasainya. Masa remaja memang sangat memperhatikan masalah seksual. Banyak remaja yang menyukai bacaan porno, melihat film-film porno. Semakin bertambah jika mereka berhadapan dengan rangsangan seks seperti suara, pembicaran, tulisan, foto, sentuhan, dan lainnya. Hal ini akan mendorong remaja terjebak dengan kegiatan seks yang haram.

Perawatan organ reproduksi tidak identik dengan pemanfaatan tanpa kendali. Sistem organ reproduksi dalam pertumbuhannya sebagaimana organ lainnya, memerlukan masa tertentu yang berkesinambungan sehingga mencapai petumbuhan maksimal. Disinilah letak pentingnya pendamping orang tua dan pendidik untuk memberi pemahaman yang benar tentang pertumbuhan organ reproduksi. Pemahaman remaja berkaitan dengan organ reproduksinya tentunya ditanamkan sesuai dengan kadar kemampuan logika dan umur mereka. Dengan demikian remaja tidak akan cemas ketika menghadapi peristiwa haid pertama, melewati masa premenstrual syndrome dengan aman, memahami hukum fiqh terkait dengan haid serta peristiwa lain yang mengiringi masa pubertas remaja.

Kematangan aspek seksual primer biasanya berhubungan dengan alat-alat reproduksi yang ditandai dengan haid pertama pada remaja putri, dan mimpi basah pada remaja putra. Kematangan aspek seksual sekunder, biasanya berhubungan dengan perkembangan bentuk fi- 
sik maupun fungsi fisiologis yang berhubungan dengan kematangan fisik, yaitu dari fisik anak menuju fisik dewasa. Selain itu remaja juga mengalami transisi kehidupan seksualitas, yaitu dari kehidupan seksualitas anak menuju kehidupan seksualitas dewasa. Transisi yang dialami remaja ini dapat menyebabkan perubahan dalam kehidupan seksualnya, yaitu antara lain munculnya perhatian dan minat yang tertuju pada anggota kelompok lawan jenis. Selama perubahan ini dipengaruhi oleh fungsi hormon-hormon seksual, yaitu testosteron untuk laki-laki dan progesteron serta estrogen untuk perempuan. Hormon-hormon ini jugalah yang berpengaruh terhadap dorongan seksual remaja.

Remaja juga harus bisa menjaga diri (isti'taaf). Hal ini mampu dilakukan pada remaja yang mempunyai kejelasan konsep hidup dalam menjalani hidupnya. Orang tua sejak usia dini harus menanamkan dasar yang kuat pada diri anak bahwa Allah menciptakan manusia untuk beribadah kepada-Nya. Jika konsep hidup yang benar telah tertanam maka remaja akan memahami jati dirinya, menyadari akan tugas dan tanggung jawabnya, mengerti hubungan dirinya dengan lingkungaanya. Kualitas akhlak akan terus terpupuk dengan memahami batas-batas nilai, komitmen dengan tanggung jawab bersama dalam masyarakat. Remaja akan merasa damai di rumah yang terbangun dari keterbukaan, cinta kasih, saling memahami di antara sesama keluarga. Pengawasan dan bimbingan dari orang tua dan pendidik akan menghindarkan dari pergaulan bebas, komitmen terhadap aturan Allah baik dalam aurat (pakaian), pergaulan antar lawan jenis dan sebagainya.

Biasanya orang tua terlalu percaya terhadap anaknya, sehingga membebaskan anaknya untuk melakukan apa yang mereka su-ka, dengan atau tanpa diketahui oleh orangtua mereka. Sebenarnya masalah ini mungkin bisa sedikit dicegah dengan memberikan pelajaran tentang moral dan agama, kalau perlu pelajaran tentang seks juga, agar anak tahu apa saja bahayanya apabila melakukannya.

Kebanyakan remaja melakukan itu tanpa berfikir panjang terlebih dahulu, bagaimana nanti nasib si anak tersebut saat nanti ingin menikah, terutama remaja perempuan. Bahaya yang ditimbulkan dari seks bebas itu cukup banyak. Biasanya penyakit kelamin seperti sifilis, herpes, dan lain lainnya akan timbul setelah melakukannya terhadap banyak pasangan. Sungguh hal seperti ini tidak diinginkan oleh siapapun.

Namun semua itu kembali lagi ke remaja tersebut, bagaimanapun sehebat hebatnya orang tua dalam mendidik anak, semua tergantung dari individu remaja tersebut. Mungkin lebih baik apabila orang tua memberikan pendididkan tentang seks agar di pikiran remaja tersebut tidak timbul rasa penasaran. Dan hanya melakukan seperti itu setelah menikah saja, dan tentunya hanya dengan satu pasangan saja.

Seks bebas merupakan cara mengekspresikan cinta yang paling melanggar normanorma masyarakat. Seks bebas juga merupakan sesuatu hal yang "anehnya" mulai dianggap hal yang biasa bagi beberapa remaja di Indonesia. Hal ini tidak terlepas dari media-media massa/elektronik, westernisasi (kebarat-baratan) ataupun salah pergaulan. Mereka yang kurang pendidikan agamanya atau mereka yang kurang terdidik moral nya dan lebih sering melihat atau menonton acara-acara yang dianggap menjadi dasar dari perbuatannya, seperti sinetron atau film, tentu saja hal ini akan membentuk perilaku remaja yang cenderung tersesat dalam pergaulan nya atau lebih bisa lebih buruk lagi.

Remaja dalam perkembangannya memerlukan lingkungan adaptip yang menciptakan kondisi yang nyaman untuk bertanya dan membentuk karakter bertanggung jawab terhadap dirinya. Ada kesan pada remaja, seks itu menyenangkan, puncak rasa kecintaan, yang serba membahagiakan sehingga tidak perlu ditakutkan. Berkembang pula opini seks adalah sesuatu yang menarik dan perlu dicoba (sexpectation). Dampak pergaulan bebas mengantarkan pada kegiatan menyimpang seperti seks bebas, tindak kriminal termasuk aborsi, narkoba, serta berkembangnya Penyakit Menular Seksual (PMS).

Pendidikan seks di kalangan remaja tampaknya belum terlihat realisasinya, terbukti dengan banyaknya kasus tentang kehamilan di luar nikah atau penyakit menular seperti HIV/ AIDS dan sebagainya. Memang tidak semua remaja harus diberi pengarahan tentang hal ini karena mereka seharusnya sudah dapat berpikir secara matang tentang nilai-nilai atau normanorma yang berlaku di masyarakatnya. Namun, sebagaimana yang kita ketahui bersama, bahwa remaja cenderung labil dalam emosi dan 
pengetahuan serta pengalaman yang dimiliki mereka masih belum bisa membuat remaja itu menentukan tindakannya secara benar. Hal inilah yang menyebabkan seks bebas di kalangan remaja semakin memburuk. Tentu masih banyak penyebab-penyebab remaja cenderung melakukan seks bebas.

Berdasarkan penelitian di berbagai kota besar di Indonesia, sekitar 20 hingga 30 persen remaja mengaku pernah melakukan hubungan seks. Perilaku seks bebas tersebut berlanjut hingga menginjak ke jenjang perkawinan. Ancaman pola hidup seks bebas remaja secara umum baik di pondokan atau kos-kosan tampaknya berkembang semakin serius.

Pakar seks juga spesialis Obstetri dan Ginekologi Dr. Boyke di Jakarta mengungkapkan, dari tahun ke tahun data remaja yang melakukan hubungan seks bebas semakin meningkat. Dari sekitar 5\% pada tahun 1980-an, menjadi 20\% pada tahun 2000.

Kisaran angka tersebut, kata Boyke, dikumpulkan dari berbagai penelitian di beberapa kota besar di Indonesia, seperti Jakarta, Surabaya, Palu dan Banjarmasin. Bahkan di pulau Palu, Sulawesi Tenggara, pada tahun 2000 lalu tercatat remaja yang pernah melakukan hubungan seks pranikah mencapai 29,9 persen. "sementara penelitian yang saya lakukan pada tahun 1999 lalu terhadap pasien yang datang ke Klinik Pasutri, tercatat sekitar 18 persen remaja pernah melakukan hubungan seksual pranikah," kata pemilik Klinik Pasutri ini.

Fenomena ini terjadi pada remaja mesjid, mereka yang suka melakukan kegiatan keagamaan dan melaksanakan perintah Allah seperti berpuasa, sering melaksanakan shalat, mengikuti kegiatan Idul Adha, mengadakan kegiatan ziarah, sampai ada yang keluaran pesantren. Ketika di tanya pada salah satu remaja mereka bahakan antusias ketika dilibatkan pada acara keagamaan. Tetapi di sisi lain mereka juga sering melakukan seks bebas seperti suka melakukan hubungan suami istri, sering berganti-ganti pasangan dalam melakukan hubungan seks bebas, menyewa PSK baik itu dari tempat lokalisasi atau dari pinggir jalan.

Pada saat di tanya mereka tahu bahwa perbuatan itu dosa tetapi hasrat dalam dirinya tidak bisa terkontrol itu yang mereka katakan. Kadang mereka punya prinsip STMJ (Shalat Terus Maksiat Jalan). Jadi dapat dilihat dalam masalah ini ketika religiusitasnya tinggi seks bebasnya pun tinggi. Seharusnya ketika tingkat religiusitasnya tinggi maka seks bebasnya pun pasti akan rendah karena mereka takut dosa yang akan mereka terima.

Kelompok remaja yang masuk ke dalam penelitian tersebut rata-rata berusia 13-21 tahun, dan umumnya masih bersekolah di tingkat Sekolah Lanjutan Tingkat Atas (SLTA) atau mahasiswa. Namun dalam beberapa kasus juga terjadi pada anak-anak yang duduk di tingkat Sekolah Menengah Pertama (SMP).

"Masalah seks dengan pasangannya justru dijadikan legistimasi untuk melakukan seks bebas. Bahkan, saat ini, seks bebas sudah menjadi bagian dari budaya bisnis," cetusnya. Faktor yang melatarbelakangi hal ini, ujar Boyke, antara lain disebabkan berkurangnya pemahaman nilai-nilai agama. Selain itu, juga disebabkan belum adanya pendidikan seks secara formal di sekolah-sekolah. (Disarikan dari laporan wartawan Majalah Gemari Haris Fadillah, 2001).

\section{METODOLOGI PENELITIAN}

Penelitian ini menggunakan pendekatan kuantitatif dengan metode korelasional, yaitu penelitian yang dimaksudkan untuk mengetahui ada tidaknya hubungan antara dua atau lebih variabel. Variabel pertama yang akan diteliti adalah religiusitas, yaitu kemampuan seseorang dalam menerapkan dan menginternalisasikan nilai-nilai keagamaan ke dalam kehidupannya dan tercermin dalam sikap dan perilakunya (Glock \& Stark (1969) dalam Ancok, (1996: 76)). Variabel kedua yang akan diteliti adalah perilaku seks bebas adalah segala tingkah laku yang didorong oleh hasrat seksual, baik dengan lawan jenisnya atau pun dengan sesama jenisnya (Sarlito, 1997:137).

Populasi dalam penelitian ini adalah semua remaja mesjid di desa Cikungkurak Bandung yang berjumlah 102 orang dan tersebar di 4 mesjid. Karena jumlah subjek relatif sedikit, dan dimungkinkan semua anggota populasi dijadikan sebagai subjek penelitian, maka penelitian ini akan berbentuk penelitian populasi.

Korelasi antara dua variabel dihitung dengan menggunakan perhitungan statistik korelasi Rank Spearman dengan menggunakan bantuan program SPSS (Statistical Program for Social Science) versi 17. Uji Rank Spearman digunakan dengan alasan bahwa data dalam penelitian ini berpasangan, data berskala 
ordinal dan teknik statistik berbentuk nonparametrik (Siegel. 1992)..

\section{HASIL DAN PEMBAHASAN}

\section{Hasil}

Berdasarkan hasil analisis diketahui bahwa koefisien korelasi antara religiusitas dengan perilaku seks bebas adalah sebesar $-0,187$ dengan taraf signifikansi 0,030 dan $\alpha=0,05$ dengan arah pengujian satu sisi. Kriteria uji yang digunakan adalah tolak $\mathrm{H}_{0}$ jika taraf signifikansi lebih kecil dari $\alpha$ dengan $\alpha=0.05$. Karena taraf signifikansi lebih kecil dari pada harga $\alpha$, maka $\mathrm{H}_{0}$ ditolak. Dengan demikian dapat dikatakan bahwa terdapat hubungan negatif antara religiusitas dengan perilaku seks bebas.

Hasil pengujian hipotesis menunjukkan bahwa religiusitas memilki korelasi negatif dengan perilaku seks bebas. Indeks korelasi sebesar - 0,187 tersebut memiliki arti tingkat korelasi antara tingkat religiusitas dengan perilaku seks bebas adalah rendah. Hasil pengujian tersebut, memiliki arti bahwa sebagian besar subjek yang memiliki tingkat religiusitas tinggi, memiliki tingkat perilaku seks bebas yang rendah. Sebaliknya, sebagian besar subjek yang memiliki tingkat religiusitas yang rendah, memiliki tingkat perilaku seks bebas yang tinggi.

Berdasarkan hasil analisis deskriptif diketahui bahwa dari $49 \%$ subjek yang memiliki tingkat religiusitas rendah, sebanyak $23.5 \%$ (24 orang) diantaranya memiliki tingkat perilaku seks bebas yang rendah dan 25.5\% (26 orang) lainnya memiliki tingkat perilaku seks bebas yang tinggi. Hal tersebut memiliki arti pada subjek yang memiliki tingkat religiusitas rendah jumlah subjek yang memiliki tingkat perilaku seks tinggi lebih banyak dibanding subjek yang memiliki tingkat perilaku seks rendah.

Selanjutnya, dari $51 \%$ subjek yang memiliki tingkat religiusitas tinggi, sebanyak 26 , $5 \%$ (27 orang) diantaranya memiliki tingkat perilaku seks bebas yang rendah dan $24.5 \%$ (25 orang) lainnya memiliki tingkat perilaku seks bebas yang tinggi. Hal tersebut memiliki arti pada subjek yang memiliki tingkat religiusitas tinggi jumlah subjek yang memiliki tingkat perilaku seks tinggi lebih sedikit dibanding subjek yang memiliki tingkat perilaku seks rendah.

\section{Pembahasan}

Tingkat religiusitas yang dimiliki subjek berhubungan secara negatif dengan peilaku seks bebas, sesuai dengan apa yang dikemukakan oleh Darajat (1970) bahwa agama berfungsi sebagai pengontrol, pengendali dan pengarah bagi tingkah laku individu. Artinya segala bentuk tingkah laku yang dimunculkan oleh individu berkaitan dengan sejauh mana nilai-nilai agama yang telah mereka ketahui, dihayati dan diamalkan sehingga perilaku yang muncul tidak bertentangan dengan nilai-nilai agama. Selain itu, tanpa adanya nilai-nilai agama yang diyakini maka individu akan mudah terpengaruh oleh lingkungan diluar dirinya yang bisa memberikan dampak positif maupun negatif. Dampak negatif dapat memunculkan tingkah laku yang tidak sesuai dengan auran agama dan aturan masyarakat seperti perilaku seks bebas. Jadi jika remaja tersebut tidak mempunyai komitmen di dalam dirinya maka akan lebih mudah terjerumus pada perilaku seks bebas. Sebaliknya jika mereka mempunyai komitmen yang kuat untuk tidak melakukan hal-hal yang dilarang agama maka seks bebas tidak akan terjadi.

Religiusitas bukan hanya yang berkaitan dengan aktifitas yang tampak dan dilihat oleh mata, tetapi juga aktifitas yang tampak dan terjadi dalam hati seseorang. Religiusitas melibatkan fungsi jiwa rasa manusia karena didalamnya mencangkup aspek-aspek kognitif, yang nampak dalam keimanan dan kepercayaan, afektif terlibat dalam ketuhanan dan rasa keagamaan serta kerinduan pada Tuhan, dan konatif nampak dalam perbuatan dan gerakan tingkah laku keagamaan. Aspek-aspek tersebut merupakan suatu sistem kesadaran beragama yang telah ada dalam kepribadian seseorang (Ahyadi, 1991: 70). Aspek-aspek ini terkandung dalam dimensi-dimensi religiusitas. Menurut Glock \& Stark ada 5 macam dimensi religiusitas yaitu pengetahuan, keyakinan, praktek agama, pengalaman dan konsekuensi.

Dimensi pengetahuan agama mengacu pada sejauhmana individu memiliki pengetahuan mengenai keagamaan yang melibatkan aspek kognitif. Tingkat pengetahuan yang tinggi dalam berbagai bidang agama akan membuat individu berfikir beberapa kali ketika ia akan melakukan perlaku seks bebas, sehingga tingkat perlaku seks bebasnya pun akan menjadi rendah. Sebaliknya individu yang memi- 
liki tingkat pengetahuan tentang agama yang rendah akan melakukan perilaku seks bebas tanpa berpikir panjang terlebih dahulu sehingga tingkat perilaku seks bebasnya menjadi tinggi.

Dimensi keyakinan mengacu pada kenyatan bahwa agama patut diterima karena kebenarannya. Tingkat keyakinan yang tinggi akan adanya berbagai hal ghaib yang diceritakan dalam agama akan membuat remaja selalu merasa diawasi dan dicatat perilakunya. Sehingga ia akan merasa selalu diawasi ketika akan melakukan sesuatu yang bertentangan dengan agama termasuk perilaku seks bebas, akibatnya tingkat perilaku seks bebasnya akan rendah. Sebaliknya remaja yang tidak merasa diawasi akan memunculkan tingkat perilaku seks bebas yang tinggi.

Dimensi praktek agama mengacu pada perilaku ketaatan dan hal-hal yang dilakukan orang untuk menunjukkan komitmen terhadap agama yang dianutnya. Dengan melaksanakan shalat, puasa, infak, shodaqoh dan juga kegiatan-kegiatan agama lainnya. Islam mengajarkan bahwa sholat itu dapat mencegah perbuatan keji dan munkar. Hal tersebut dapat dipahami karena dorongan-dorongan seks yang dimiliki remaja dapat disalurkan melalui aktivitas praktek agama, sehingga tingkat perilaku seksnya menjadi rendah. Sedangkan remaja yang menyalurkan dorongan seksnya dengan berpacaran akan memiliki tingkat perilaku seks yang tinggi.

Dimensi pengalaman bahwa ketika individu mampu berhubungan / berkomunikasi dengan hal supranatural yaitu Tuhan. Individu tersebut mampu merasakan kehadiran Tuhan dan merasakan adanya Tuhan bersamanya artinya individu tersebut merasa dekat dengan Tuhan. Individu merasakan petunjuk dari Tuhan dengan mendapatkan kemudahan yang diharapkan. Kemudian individu merasakan perasaan berdosa jika melakukan hal-hal yang tidak benar/tidak sesuai dengan norma-norma agama yang berlaku. Ketika perasaan ini muncul pada remaja, maka ia akan merasa takut Tuhan tidak menyertainya lagi ketika ia melanggar aturanNya, sehingga tingkat perilaku seksnya akan menjadi rendah. Sebaliknya remaja yang tidak memiliki peasaan dekat dengan tuhan akan melakukan perilaku apa saja tanpa kendali termasuk berpacaran, sehingga tingkat perilaku seksnya akan menjadi tinggi.
Dimensi konsekuensi berhubungan dengan empat aspek yang sudah dijelaskan sebelumnya. Jika aspek sebelumnya hanya menggariskan bagaimana pemeluknya seharusnya berfikir dan bertindak dalam kehidupan seharihari. Maka aspek ini mengatur konsekuensi agama yang berasal dari komitmen agama itu sendiri apabila aspek sebelumnya dilanggar. Akibatnya ketika remaja akan melakukan perilaku seks bebas ia merasa takut akan mendapat balasan atas perbuatannya, sehingga tingkat perilaku seks bebasnya akan menjadi rendah. Sedangkan remaja yang memiliki tingkat keyakinan yang rendah tidak akan memiliki perasaan takut, sehingga tingkat perilaku seks bebasnya menjadi tinggi.

Berdasarkan apa yang telah diuraikan bahwa agama sangatlah penting dalam kehidupan seseorang bukan saja dengan perilaku seksual saja tetapi juga dengan perilaku-perilaku yang lain. Sesuai apa yang diungkapkan oleh Darajat (1970) bahwa jika dalam kepribadian itu tidak tertanam nilai-nilai agama, maka akan mudahlah orang melakukan segala sesuatu menurut dorongan dan keinginan jiwanya tanpa mengindahkan kepentingan dan hak orang lain, ia selalu didedak oleh keinginankeinginan dan kebutuhan-kebutuhan yang pada dasarnya tidak mengenal batas hukum dan norma-norma. Tetapi jika dalam kepribadian seseorang tertanam pemahaman, penghayatan serta pengamalan nilai-nilai agama yang dalam, maka segala keinginan serta kebutuhannya akan dipenuhi dengan cara yang tidak melanggar hukum-hukum agama.

Terdapat hal menarik dari data deskriptif yang dijelaskan sebelumnya, yaitu terdapat sebagian $(23.5 \%)$ subjek yang memiliki tingkat religiusitas yang rendah namun memiliki tingkat perilaku seks bebas yang rendah pula. Sebaliknya sebagian $(24.5 \%)$ subjek lainnya yang memiliki tingkat religiusitas yang tinggi namun memiliki tingkat perilaku seks bebas yang tinggi pula.

Berdasarkan hasil wawancara dengan beberapa subjek, pada dasarnya mereka suka melakukan kegiatan keagamaan dan melaksanakan perintah Allah seperti berpuasa, sering melaksanakan shalat, mengikuti kegiatan Idul Adha, mengadakan kegiatan ziarah. Tetapi di sisi lain mereka juga sering melakukan seks bebas seperti melakukan hubungan intim dengan pacar, sering berganti-ganti pasangan dalam melakukan hubungan seks bebas, menye- 
wa PSK baik itu dari tempat lokalisasi atau dari pinggir jalan. Pada saat ditanya mereka tahu bahwa perbuatan itu dosa tetapi hasrat dalam dirinya tidak bisa terkontrol itu yang mereka katakan. Kadang mereka punya prinsip STMJ (Shalat Terus Maksiat Jalan). Menurut peneliti hal tersebut dipengaruhi oleh beberapa hal, diantaranya:

Pertama, adanya kekangan agama. Berdasarkan hasil penelitian diketahui bahwa terdapat remaja yang memiliki tingkat religiusitas tinggi sekaligus memiliki tingkat perilaku seks bebas yang tinggi pula. Menurut Jensen (dalam Sarlito, 2006) hal tersebut dapat terjadi karena masalah seksualitas pada remaja salah satunya bisa muncul karena masalah tersebut dianggap tabu/larangan. Norma-norma agama melarang seseorang untuk melakukan hubungan seks sebelum menikah. Bahkan larangan-larangan tersebut berkembang lebih jauh kepada tingkah laku yang lain, seperti berciuman dan masturbasi. Meskipun muatan pendidikan agama di pesantren maupun tempat pengajian lebih banyak, tetapi tetap terdapat kekurangan. Salah satu kekurangan yang dimiliki suatu institusi agama adalah terkadang penjelasan agama mengenai larangan dari hubungan seks sebelum nikah hanya sebatas bahwa perbuatan tersebut adalah dosa dan dosa itu sangat dibenci Allah SWT serta Allah SWT akan menghukum umatnya yang berdosa di neraka, biasanya tanpa ada penjelasan lebih jauh yang dianggap logis. Hal tersebut apabila tidak dijelaskan kepada siswa secara mendalam dengan pendekatan ilmiah yang lebih bisa diterima oleh logika justru akan membuat siswa semakin penasaran dan mencari sumber lain yang belum tentu bisa dipertanggungjawabkan.

Kedua, labilnya emosi remaja. Adanya remaja yang memiliki tingkat religiusitas tinggi serta memiliki tingkat perilaku seks yang tinggi dapat pula berhubungan dengan labilnya emosi remaja. Menurut Hurlock (1999) pada umumnya remaja memiliki kondisi emosi yang labil, pengalaman emosi yang ekstrem dan selalu merasa mendapatkan tekanan. Remaja cenderung labil dalam emosi dan pengetahuan serta pengalaman yang dimiliki mereka masih belum bisa membuat remaja itu menentukan tindakannya secara benar. Hal inilah yang menyebabkan seks bebas di kalangan remaja semakin memburuk.

Ketiga, pengaruh buruk teman sebaya. Monks, dkk (1999) menyebutkan dua bentuk perkembangan sosial remaja yaitu, pertama memisahkan diri dari orangtua dan kedua menuju kearah teman sebaya. Remaja berusaha melepaskan diri dari otoritas orangtua dengan maksud menemukan jati diri. Remaja lebih banyak berada di luar rumah dan berkumpul bersama teman sebayanya dengan membentuk kelompok dan mengeksperesikan segala potensi yang dimiliki. Kondisi ini membuat remaja sangat rentan terhadap pengaruh teman dalam hal minat, sikap penampilan dan perilaku. Perubahan yang paling menonjol adalah hubungan heteroseksual. Remaja akan memperlihatkan perubahan radikal dari tidak menyukai lawan jenis menjadi lebih menyukai, dan bahkan diakhiri dengan perilaku seks bebas.

Tingkat religiusitas ternyata tidak berhubungan dengan tingkat perilaku seks bebas bagi beberapa subjek. Hasil penelitian menunjukkan bahwa terdapat beberapa subjek yang memiliki tingkat religiusitas tinggi tetapi menunjukkan perilaku seks bebas yang tinggi pula. Berdasarkan pendapat Monks, dkk (1999) hal tersebut dapat terjadi apabila subjek berada di lingkungan teman sebaya yang sebagian besar memiliki tingkat perilaku seks bebas yang tinggi.

Berdasarkan penjelasan tersebut dapat dipahami mengapa terdapat subjek yang memiliki tingkat religiusitas rendah tetapi menunjukkan tingkat perilaku seks bebas yang rendah pula. Hal tersebut dapat terjadi karena beberapa subjek tersebut bergabung dengan teman sebaya yang memegang prinsip virginitas, bergabung di lembaga yang memberikan penjelasan bahaya perilaku seks bebas secara lebih rasional, ada juga subjek yang menggunakan norma lain selain norma agama, seperti norma sosial dan norma budaya yang memberikan sanksi yang lebih terlihat seperti pengucilan.

Keempat, adanya informasi negatif dari media massa. Seks bebas merupakan cara mengekspresikan cinta yang paling melanggar norma-norma masyarakat. Seks bebas juga merupakan sesuatu yang mulai dianggap hal yang biasa bagi beberapa remaja di Indonesia. Hal ini tidak terlepas dari media-media massa/ elektronik yang menggembar-gemborkan budaya westernisasi (kebarat-baratan). Mereka yang kurang terdidik moralnya dan lebih sering melihat atau menonton acara-acara yang dianggap menjadi dasar dari perbuatannya, seperti sinetron atau film, tentu saja hal ini akan membentuk perilaku remaja yang cenderung 
tersesat dalam pergaulan nya atau lebih bisa lebih buruk lagi.

\section{SIMPULAN DAN SARAN}

\section{Simpulan}

Berdasarkan hasil analisis dan pembahasan tentang hubungan antara tingkat religiusitas dengan perilaku seks bebas pada remaja mesjid di desa Cikungkurak Bandung dapat ditarik simpulan bahwa terdapat hubungan negatif antara tingkat religiusitas dengan perilaku seks bebas pada remaja mesjid di Desa Cikungkurak Bandung.

\section{Saran}

Berdasarkan hasil penelitian yang telah dilakukan, dengan memperhatikan keterbatasan-keterbatasan dalam penelitian ini, peneliti mengajukan saran-saran agar dapat dijadikan bahan pertimbangan sebagai berikut:

Bagi remaja mesjid, diharapkan untuk mencari informasi yang lebih jelas dan dapat dipertanggung jawabkan mengenai masalah seks pada orang tua, guru, konselor atau LSM yang bergerak dibidang penyuluhan mengenai kesehatan reproduksi, bahaya HIV/AIDS dan sebagainya.

Bagi pihak DKM, harap menjadi bahan pertimbangan untuk memasukan pendidikan seks (sex education) yang sesuai syari'ah ke dalam bahan pembahasan dalam pengajian.

Bagi pihak keluarga, supaya lebih terbuka dalam membicarakan masalah seks supaya anak tidak mencari informasi dari sumber lain yang tidak bisa dipertanggungjawabkan.

Untuk penelitian selanjutnya, karena pada penelitian ini masih terdapat kasus yang cukup menarik dan perlu dijawab serta diteliti kembali yaitu terdapat subjek yang memiliki tingkat religiusitas yang rendah namun memiliki tingkat perilaku seks bebas yang rendah, begitu pula sebaliknya terdapat subjek yang memiliki tingkat religiusitas tinggi yang memiliki tingkat perilaku seks bebas yang tinggi. Karenanya, peneliti memberi masukkan kepada peneliti lain untuk mencari variabel lain yang diduga memiliki hubungan yang lebih signifikan dengan perilaku seks bebas serta menjaring data-data kualitatif lebih banyak lagi sebagai bahan untuk menunjang dan melengkapi hasil data kuantitatif, sehingga dapat menghasilkan analisis yang lebih akurat lagi.

\section{DAFTAR PUSTAKA}

Ancok, Djamaludin. 1989. Teknik Penyusunan Skala Pengukuran. Yogyakarta: Pusat Penelitian Kependudukan UGM.

Ancok, J \& Nashori S, Fuat. 1994. Psikologi Islami. Yogyakarta : Pustaka Pelajar.

Agustian, K. 2009. Seks Bebas di Kalangan Remaja. diambil dari www.krisnaagustian. ngeblogs.com.

Al-Miqwar, M. 2006. Psikologi Remaja. Bandung : CV Pustaka Setia.

Arikunto, S. 1995. Manajemen Penelitian. Jakarta : Erlangga.

Atkinson, Rita L., Atkinson, Richard C., \& Hilgard, Ernest R. Pengantar Psikologi. Jilid 2. Jakarta: Erlangga.

Azwar, S. 2004. Penyusunan Skala Psikologi. Yogyakarta: Pustaka Pelajar Offset.

Darajat, Zakiah. 1970. Peranan Agama dalam Kesehatan Mental. Jakarta: Gunung Agung.

Dewi, M. 2009. Seks Bebas di Kalangan Remaja. diambil dari www.wikimu.com.

Harianku. 2008. Seks Bebas di Kalangan Remaja. diambil dari www.harianku.com

Hurlock, E. 1973. Adolescent Development. Kogakusha : Mc Graw Hill.

Hurlock, E.B. 1996. Developmental Psychology a Life Span Approach. 5th edition. Jakarta: Erlangga.

Jalaludin. 1996. Psikologi Agama. Jakarta: Rajawali Pers.

Kadir, Muslim A. 2009. Aktifitas Membaca Buku Ilmu Islam Terapan. diambil dari www.blog.beswandjarum.com

Papalia, Diane E,et al. 2008. Human Development (Psikologi Perkembangan). Jakarta : Kencana

S, R.M. Hadi Suryo. 2009. Fenomena Seks Bebas di Kalangan Remaja, Haruskah di Biarkan?. http://indonesianyouthconference.org.

Sarwono, Sarlito W. (2006). Psikologi Remaja. Jakarta: PT Raja Grafindo Persada

Santrock, John. W. 2003. Adolescence (Perkembangan Remaja), 6th edition. Jakarta : Erlangga.

Siegel, Sidney. 1992. Statistik Non Parametri untuk Ilmu-ilmu Sosial. Jakarta: PT Gramedia Pustaka Utama. 
Sudjana. 1996. Metoda Statistik. edisi keempat. Bandung : Tarsito

Suryani, Sri. 2008. Studi Komparatif tentang Kompetensi Interpersonal pada Mahasiswa Yang Aktif dan Tidak Aktif Dalam Organisasi. UNPAD: Skripsi tidak dipublikasikan
Syarif. 2008. Dampak Perilaku Seks Bebas bagi Kesehatan Remaja. Diambil dari www.halalsehat.com.

Wirawan, S. 1997. Psikologi Remaja. Jakarta : Rajawali Pers.

Whandi. 2009. Waspadai Seks Bebas Kalangan Remaja. Majalah Gemari. Diambil dari www.whandi.net. 